\title{
BIOASSAY-GUIDED ISOLATION OF THE MAJOR COMPOUND WITH ANTIOXIDANT ACTIVITY FROM THE ALGERIAN MEDICINAL PLANT BUBONIUM GRAVEOLENS
}

\author{
RADJA MESSAOUDI, ABDELKRIM CHERITI*, YOUNES BOURMITA
}

Phytochemistry and Organic Synthesis Laboratory, Medicinal Faculty, UTMB, 08000 Bechar, Algeria. Email: karimcheriti@yahoo.com

Received: 16 July 2018, Revised and Accepted: 20 September 2018

\section{ABSTRACT}

Objective: The objective of this research was to isolate and identify the major compound from the antioxidant extract obtained from the leaves of Bubonium graveolens.

Methods: A bioguided fractionation was done to isolate and identify the major compound responsible of the antioxidant activity. The chemical structure of the isolated natural compound was established by spectroscopic means including UV, Fourier transform infrared, ${ }^{1} \mathrm{H}$ NMR, and ${ }^{13} \mathrm{C}$ NMR. The purified compound was accurately tested for its antioxidant activity by the 2, 2-diphenyl-1-picrylhydrazyl assay at $517 \mathrm{~nm}$.

Results: The major compound named myricetin $3^{\prime}$-O-rhamnoside was isolated for the $1^{\text {st }}$ time from the leaves of B. graveolens a medicinal specie of Algerian Sahara belonging to the Asteraceae family. The study showed that the myricetin 3'-0-rhamnoside has an antioxidant potential $59 \%$ when compared with standard ascorbic acid with an $\mathrm{IC}_{50}=0.916 \mathrm{mg} / \mathrm{ml}$.

Conclusion: In the present work, it was possible to isolate and identify for the $1^{\text {st }}$ time the major compound from the antioxidant fraction of $B$. graveolens.

Keywords: Bubonium Graveolens, Antioxidant activity, Asteraceae, Medicinal plants, Sahara.

(C) 2018 The Authors. Published by Innovare Academic Sciences Pvt Ltd. This is an open access article under the CC BY license (http://creativecommons. org/licenses/by/4. 0/) DOI: http://dx.doi.org/10.22159/ajpcr.2018.v11i11.28514

\section{INTRODUCTION}

South Algeria with its rich floral resources and ethnobotanical history is an ideal place of new pharmacological compounds [1,2]. One of these floral resources is Bubonium graveolens (Forssk.), Maire locally known as "Tafss" belongs to the Asteraceae family, it is considered synonymous with Asteriscus graveolens (Forssk.), Buphthalmum graveolens (Forssk.), and Nauplius graveolens (Forssk.) subsp [3]. This Saharan medicinal plant is widely represented in south-west of Algeria and south-east of Morocco [3], in Sahara folk medicine, this species is used as stomachic, treating fever, gastrointestinal tracts, cephalic pains, bronchitis, and as anti-inflammatory [4,5] and also previous studies revealed that the extracts from this species have an antifungal effect against Fusarium oxysporum [6], antioxidant [7], and antimicrobial activity [8,9].

Phytochemical investigations on the species have led to the isolation of numerous and varied secondary metabolites; monoterpenes $[4,10]$, sesquiterpene [11-13], and flavonoids [14]. It is well reported that polyphenol compounds have attracted considerable attention due to their pharmacological properties like flavones who were previously revealed a high-efficiency biological activity [15-18].

The study of chemicals compositions of plants is on the basis of isolation and identification of compounds by various chromatographic methods (TLC, CC, high-performance liquid chromatography, gas chromatography) and spectroscopics [19] such as the UV-Vis, infrared (IR) spectroscopy, mass spectrometry, and nuclear magnetic resonance (NMR) spectroscopy that offers the most useful and valuable information about the structure of natural products. These techniques are all important tools for a proper identification of the components of an extract [20]. In this context, we include a research on the Saharan medicinal plant Bubonium graveolens.

\section{Experimental}

The chemicals used were in analytical grade and purchased from the Sigma-Aldrich. UV spectra measurement (Unicam UV 300 and Specord 200 Plus), IR spectra (Thermo Nicolet Avatar 320 FT-IR spectrophotometer), NMR spectra (Bruker Avance GP 250,1H: $250 \mathrm{MHz}$; 13C: $63 \mathrm{MHz}$ ), TLC was performed on silica gel coated aluminum plates (Merck kieselgel 60 F254, Germany) and column chromatography was performed over silica gel 60 (Merck, particle size 230-400 mesh).

\section{METHODS}

Leaves of B. graveolens were collected during the flowering period March 2015 in south-western Algeria. A voucher specimen has been deposited in the herbarium of POSL Laboratory (UTMB, Algeria) under Accession $\mathrm{N}^{\circ}$ CA 00/14.

\section{Extraction and isolation}

Air-dried and powdered leaves of B. graveolens (240 g) were extracted with water/acetone $(30 / 70)$ under reflux and the hydroacetone solution was concentrated by evaporation up to $1 / 3$ of the initial volume [21]. The extract was fractioned by the following solvents with increasing polarity: Hexane $(3 \times 150 \mathrm{ml})$, diethyl ether $(3 \times 150 \mathrm{ml})$, ethyl acetate $(3 \times 150 \mathrm{ml})$, and butanol $(3 \times 150 \mathrm{ml})$. The diethyl ether fraction was concentrated to dryness by rotary evaporator providing $2.86 \mathrm{~g}$ of residue which was divided into fractions to isolate a pure compound by a successive column chromatography on silica gel, eluting with heptane/acetone/ethyl acetate/formic acid (5/2/2.9/0.1).

\section{Scavenging 2, 2-diphenyl-1-picrylhydrazyl (DPPH) radical test} The free radical scavenging activity of the major compound was measured in vitro by DPPH assay according to the method described earlier [22,23]. Briefly, the DPPH methanolic solution $(25 \mu \mathrm{g} / 100 \mathrm{ml})$ was mixed with samples in four concentrations and left to stand at room temperature in a dark place for $30 \mathrm{~min}$. Absorbance was read using a spectrophotometer at $517 \mathrm{~nm}$. The ability of pure compound to scavenge DPPH was calculated using the following equation:

Radical scavenging activity $\%=$ Control OD - Sample OD $/$ Control OD

Where, OD: optic density. 
Reference standard compound being used was ascorbic acid and experiment was done in triplicate. The $50 \%$ inhibition $\left(\mathrm{IC}_{50}\right)$ of antioxidant activity was calculated as the concentrations of samples that inhibited $50 \%$ of scavenging activity of DPPH radical activity [24].

\section{General procedure}

UV spectra were obtained in $\mathrm{MeOH}$ solvent with Unicam UV 300 spectrophotometer and Specord 200 Plus spectrophotometer. IR spectra were obtained with a Thermo Nicolet Avatar 320 Fourier transform-IR spectrophotometer. The NMR spectra were taken on a Bruker Avance GP $250\left({ }^{1} \mathrm{H}\right.$ : $250 \mathrm{MHz} ;{ }^{13} \mathrm{C}$ : $\left.63 \mathrm{MHz}\right)$ Spectrometer. Column chromatography was performed over silica gel 60 (Merck, particle size 230-400 mesh)

\section{RESULTS AND DISCUSSION}

Bioguided fractionation was been done on a mass (2.86 g) of diethyl ether extract. A successive column chromatography was used to separate the major compound. After several chromatographic analyses, we regrouped the major compound from the fractions 36 to 43 with RF 0.43 and yellow color (Fig. 1)

UV: 250, 359 nm. IR (cm-1) (KBr): 3227, 2929, 2874, 1733, 1640, 1515, 1369, 1298, 976, 913 and $864 \mathrm{~cm}^{-1} .{ }^{1} \mathrm{H}$ NMR: H2' ( $\delta$ 7.17, d, 1H); H6' $(\delta 6.64, \mathrm{~d}, 1 \mathrm{H}) ; \mathrm{H} 6(\delta 6.44, \mathrm{~m}, 1 \mathrm{H})$; H8 $(\delta 6.38, \mathrm{~m}, 1 \mathrm{H}), \delta 0.93(\mathrm{~d}, 3 \mathrm{H}$, glucoseCH3) 3.26 (m glucose proton) $5.02(\mathrm{~m}$, glucosyl $1 \mathrm{H}) .{ }^{13} \mathrm{C}$ NMR(DMSO-d $)$ : $\delta 18\left(\mathrm{C}-6^{\prime \prime}\right), \quad 76\left(\mathrm{C}-2^{\prime \prime}\right), \quad 77\left(\mathrm{C}-5^{\prime \prime}\right), \quad 77\left(\mathrm{C}-3^{\prime \prime}\right), \quad 78\left(\mathrm{C}-4^{\prime \prime}\right), 87(\mathrm{C}-6), 85(\mathrm{C}-$

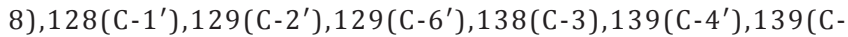
2),143(C-3'), 147(C-5'), 150(C-9), 155(C-5), $170(\mathrm{C}-4), 171(\mathrm{C}-7)$.

The major compound (flavonol glycoside) isolated from B. graveolens as a yellow amorphous powder $[\alpha]_{\mathrm{D}}^{25}=2.5$ with a melting point $120^{\circ} \mathrm{C}$. The IR spectra showed frequency at $3227 \mathrm{~cm}^{-1}$ indicating the presence of hydroxyl group in conjugation [25], the valence vibration of the cyclic ketones $(\mathrm{C}=0)$ is located at $1640 \mathrm{~cm}^{-1}$ and phenyl groups at $1515 \mathrm{~cm}^{-1}$, and the aromatic links $\mathrm{C}-\mathrm{H}$ are presented in the IR spectra at $2929 \mathrm{~cm}^{-1}$ [26]. The frequency of vibration (976 and $913 \mathrm{~cm}^{-1}$ ) corresponds to the distortion vibration out of the plan of the unsaturated hydrocarbons [27].

An examination of the NMR data and a comparison with the literature suggested that the isolated compound was a flavonol glycoside. Thus, the ${ }^{1} \mathrm{H}$-NMR spectrum revealed characteristic resonances of aromatic protons such as H2' $(\delta 7.17, \mathrm{~d}, 1 \mathrm{H}), \mathrm{H} 6^{\prime}(\delta 6.64, \mathrm{~d}, 1 \mathrm{H}), \mathrm{H} 6(\delta 6.44, \mathrm{~m}, 1 \mathrm{H})$, and $\mathrm{H} 8(\delta 6.38, \mathrm{~m}, 1 \mathrm{H})$. A doublet at $\delta 0.93$ indicates the presence of rhamnosyl methyl protons [28-30] and showed characteristic signal assignable to an anomeric proton [31] at $5.02 \mathrm{ppm}$. Detailed analyses of the ${ }^{13} \mathrm{C}$ NMR spectrum of this compound indicated the presence of a carbonyl carbon, which showed signal at $\delta 170$ (C-4), a methyl group at $\delta 17.1$, and four oxymethine carbons with chemical shifts between 76 and $78 \mathrm{ppm}$.

The big similarity of myricetin 3'-0-rhamnoside data with literature myricetin 3-0-rhamnoside data led us to conclude that the unique difference between the two compounds derives from the $\mathrm{H}$ signal of the B ring. While $\mathrm{H}-2^{\prime}$ and $\mathrm{H}-6^{\prime}$ of myricetin 3-0-rhamnoside appear at $\delta$ 6.97 as a singlet [32] in myricetin $3^{\prime}$-O-rhamnoside, they are displayed as two doublets at $\delta 6.90$ and $\delta 7.00[29,33]$. Therefore, it was evident from the above observations that the rhamnoside was attached to the C-3' oxygen of ring $\mathrm{B}$.

\section{DPPH radical scavenging activity}

The study of the hydrogen atom or electron donation ability of major compound from B. graveolens against DPPH free radical was precisely measured from the bleaching of violet-colored DPPH at $517 \mathrm{~nm}$. Lower absorbance of the reaction mixture indicated higher free radical activity [34].

Fig. 2 shows the radical scavenging activity at different concentrations of myricetin 3'-O-rhamnoside $(0,0.25,0.5,0.75$, and $1.0 \mathrm{mg} / \mathrm{ml})$.
According to the results found, the myricetin 3'-0-rhamnoside has an antioxidant potential $59 \%$ compared to the standard ascorbic acid $(86 \%)$ and $\mathrm{IC}_{50}=0.916 \mathrm{mg} / \mathrm{ml}$.

Several studies have been done to investigate the various therapeutic and biological effects of myricetin, including its use as a potent antioxidant was shown to possess significant radical scavenging activity against DPPH [35], by comparing the radical scavenging activity of our compound myricetin 3'-0-rhamnoside and myricetin3-0-galactoside and other flavonol glycoside reported in literature showed that myricetin-3-0-rhamnoside was a very potent radical scavenger with $\mathrm{IC}_{50}$ value of $1.4 \mu \mathrm{g} / \mathrm{ml}$ and myricetin-3-0-galactoside showed a scavenging activity with an $\mathrm{IC}_{50}$ value of $2.3 \mu \mathrm{g} / \mathrm{ml}[36]$ while the myricetin 3'-O-rhamnoside showed an $\mathrm{IC}_{50}=0.916 \mathrm{mg} / \mathrm{ml}$. We noted that the presence of rhamnoside in 3 ' position of $\mathrm{B}$ ring decreases the antioxidant activity, this result is an agreement with our early study that the presence of hydroxyls groups on B ring is the most significant structural parameter for the antioxidant activity [37].

\section{CONCLUSION}

The result of the study showed that the leaves of $B$. graveolens contain flavonol glycoside. The structure of the isolated compound was characterized by UV, IR, ${ }^{1} \mathrm{HNMR}$, and ${ }^{13} \mathrm{CNMR}$. The antioxidant evaluation by DPPH method showed that the isolated compound has a moderate antioxidant activity when compared to standard ascorbic

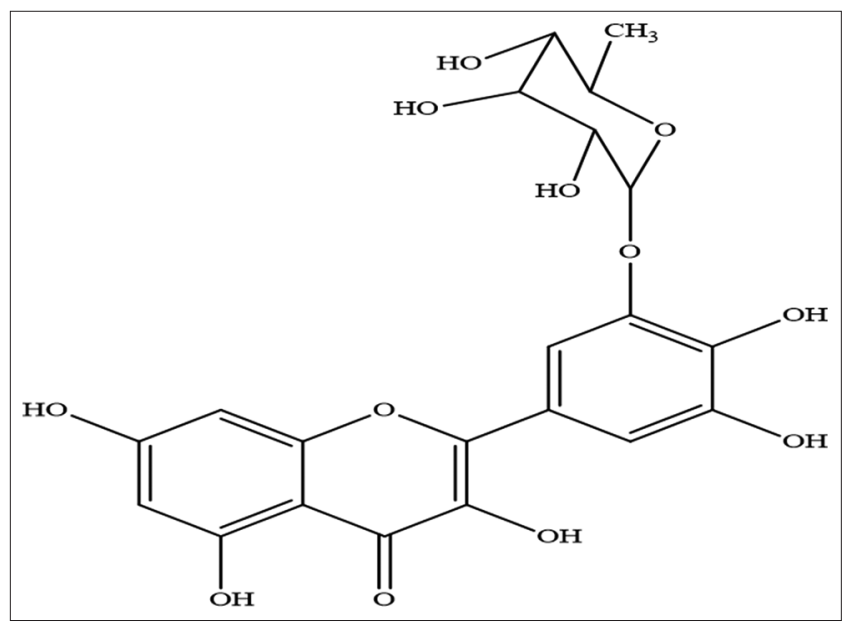

Fig. 1: Structure of the compound identified in Bubonium graveolens

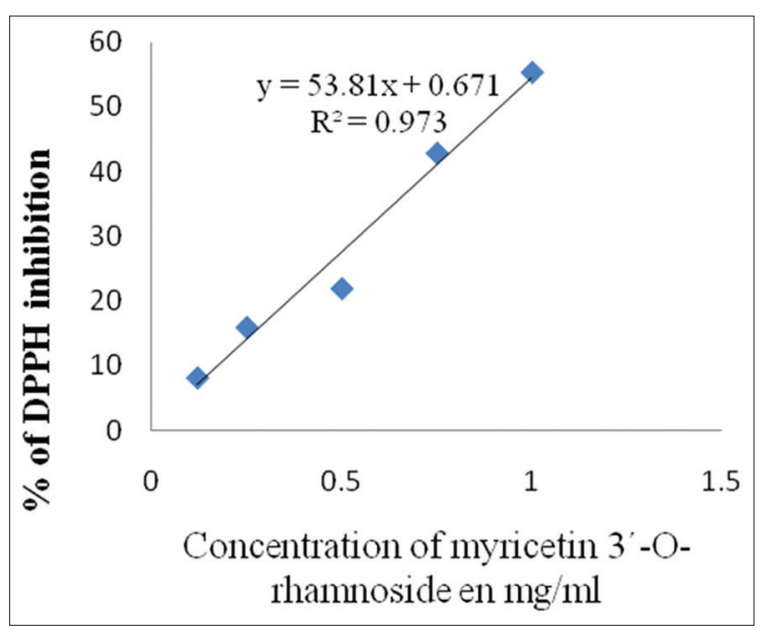

Fig. 2: Radical scavenging activity at different concentrations of myricetin 3'-0-rhamnoside 
acid. This flavonol glycoside (myricetin 3'-0-rhamnoside) was isolated for the $1^{\text {st }}$ time from $B$ graveolens.

\section{AUTHORS' CONTRIBUTION}

The experimental work was done by R. Messaoudi and Y. Bourmita under the supervision of Pr. A. Cheriti.

\section{CONFLICTS OF INTEREST}

The authors do not have any conflicts of interest to declare.

\section{REFERENCES}

1. Cheriti A, Belboukhari M, Belboukhari N, Djeradi H. Phytochemical and biological studies of Launaea Cass. Genus (Asteraceae) from Algerian Sahara. Curr Top Phytochem 2012;11:67.

2. Berreghioua A, Cheriti A. Phytochemical investigation of the medicinal plant Moricandia arvensis L. From Algerian Sahara. Asian J Pharm Clin Res 2018;11:450-3.

3. a) Cheriti A, Saad A, Belboukhari N, Ghezali S. The essential oil composition of Bubonium graveolens (Forssk) maire from the Algerian Sahara. J Flavour Fragr 2007;22:286-8. b) Keffous F, Belboukhari N, Djaradi H, Cheriti A, Sekkoum K, Aboul-Enein HY. Investigation of the antioxidant potential and total phenolics of Bubonium gravelence aerial parts. Phyto Chem Bio Sub J 2017;11:73-9.

4. Said ME, Bombarda I, Naubron JV, Vanloot P, Jean M, Cheriti A, et al. Isolation of the major chiral compounds from Bubonium graveolens essential oil by HPLC and absolute configuration determination by VCD. Chirality 2017;29:70-9.

5. Znini M, Cristofari G, Majidi L, Ansari A, Bouyanzer A, Paolini J, et al . Green approach to corrosion inhibition of mild steel by essential oil leaves of Asteriscus graveolens (Forssk.) in sulphuric acid medium. Int J Electrochem Sci 2012;7:3959-1.

6. Boulenouar N., Marouf A, Cheriti A, Belboukhari N. Medicinal plants extracts as source of antifungal agents against Fusarium oxysporum $\mathrm{f}$. Sp. Albedinis. J Agr Sci Tech 2012;14:659-69.

7. Haddouchi F, Chaouche TM, Halla N. Screening phytochimique, activités antioxydantes et pouvoir hémolytique de quatre plantes sahariennes d'Algérie, Phytothérapie 2016;14:1-9.

8. Aici D, Cheriti A, Bourmita Y, Belboukhari N. Antimicrobial activity of essential oils of Bubonium graveolens (forssk.) and Anvillea radiata (coss.). Phyto Chem Bio Sub J 2013;7:116-9.

9. Ramdane F, Essid R, Mkadmini K, Hammami M, Fares N, Mahammed MH, et al. Phytochemical composition and biological activities of Astericus graveolens (Forssk) extracts. J Process Biochem 2017;56:186-92.

10. Chaib F, Allali H, Bennaceur M, Flamini G. Chemical composition and antimicrobial activity of essential oils from the aerial parts of Asteriscus graveolens (Forssk.) less. And Pulicaria incise (Lam.) DC: Two Asteraceae herbs growing wild in the Hoggar. Chem Biodiver 2017; $14: 1700092$

11. Triana J, Eiroa JL, Morales M, Perez FJ, Brouard I, Quintana J, et al. Sesquiterpenoids isolated from two species of the Asteriscus alliance. J Nat Prod 2016:79:1292-7.

12. Sarg TM, El-Dahmy SI, Ateya AM, Abdel-Fattah HA. Two new bisabolone hydroperoxides and biological activity of Asteriscus graveolens. Fitoterapia 1994;65:241-4.

13. Akssira M., Mellouki F, Salhi A, Alilou H, Saouf A, Hanbali F, et al. Naupliolide, a sesquiterpene lactone with a novel tetracyclic skeleton from Nauplius graveolens subsp. Odorus, Tetrahedron Lett 2006;47:6719-21.

14. Ahmed AA, Ishak MS, Micheal HN, El-Ansari MA, El-Sissi HI. Flavonoids of Asteriscus graveolens. J Nat Prod 1991;54:1092-3.

15. Alilou H., Bencharki B. Activité antifongique des flavonoides isoles de la plante Asteriscus graveolens Subsp. Odorus (Schousb.) Greuter Eur Sci J 2016;12:258-70.

16. Scotti L, Fernandes MB, Muramatsu E, Emereciano VP, Tavares JF,
Silva MS, et al. 13C NMR spectral data and molecular descriptors to predict the antioxidant activity of flavonoids. Braz J Pharm 2011;47:241-8.

17. Paramdeep S, Damanpreet S, Rajesh KG. Phytoflavonoids: Antiepileptics for the future. Int J Pharm Pharm Sci 2014;6:51-66.

18. a) Kahko MP, Hopia I, Vuorela J, Rauha J, Kujal S, Heinonen M. Antioxidant activity of plant extracts containing phenolic compounds. J Agric Food Chem 1999;47:3954-62. b) Sabbagh G, Berakdar N. Molecular docking study of flavonoid compounds as inhibitors of B-ketoacyl acyl carrier proteinsynthase Ii (Kas Ii) of Pseudomonas aeruginosa. Int J Pharm Pharm Sci 2016;8:52-61.

19. Dos Santos JR, Fleurentin J. Ethnopharmacologie. Paris: Sources, Méthodes, Objectifs, ORSTOM et Société Française D'ethnopharmacologie; 1991. p. 409.

20. Neda I, Vlazan P, Pop RO, Sfarloaga P, Grozescu I, Segneanu A. Peptide and Amino Acids Separation and Identification from Natural Products, In Analytical Chemistry, Ira S. Krull editor, UK In TechOpen; 2012. p. 144.

21. Belboukhari N, Cheriti A. Flavonoids of Limoniastrum feei. Res J Phytochem 2007;1:74-8.

22. Lee SK, Mbwambo $\mathrm{ZH}$, Chung $\mathrm{H}$, Luyengi LE, Gamez RG, Kinghorn $\mathrm{AD}$, et al. High throughput screen., evaluation of the antioxidant potential of natural products. Comb J Chem 1998;1:35-46.

23. Mhlongo NY, Babu NK, Himakar RK, Sershen N, Cheriti A, Govender P. Phytochemical screening, antioxidant and antimicrobial efficacy of Protorhus longifolia (Bernh. Ex C. Krauss) Engl. (Anacardiaceae) seed extracts. Curr Trends Biotechno Pharm 2018;12:128-38.

24. Amzad M., Islam A, Jolly YN, Kabir MJ. A new favonol glycoside from the seeds of Zea Mays. Indian J Chem 2006;45:1319-21.

25. Fabiana G., Renato M, Steinhauser L, Heinzmann B, Albert K, Merfort I, et al. Four New flavonol glycosides from the leaves of Brugmansia suaveolens. Molecules 2014;19:6727-36.

26. Chang H, Ho Y, Sheu M, Lin Y, Tseng M, Wu S, et al. Antioxidant and free radical scavenging activities of Phellinus merrillii extracts. J Bot Stud 2007;48:470-7.

27. Bitam F, Letizia M, Manzo E, Dibi A, Gavagnin M. Chemical characterisation of the terpenoid constituents of the Algerian plant Launeae arborescens. Phytochemistry 2008;69:2984-92.

28. Z"uhal G, Om"ur DE. Flavonol glycosides from Asperula arvensis. Turk J Chem 2005;29:163-9.

29. Jorje MD, Frederio GC, Maria LS. Flavanol from Davilla flexuosa. J Braz Chem Soc 1996; 7:115-8.

30. Shimin L, Chih Y, Chi T. Hydroxylated plymethoxy flavones and methylated flavonoids in sweet orange (Citrus sinensis) peel. J Agric Food Chem 2006;54:4176-85.

31. Bargah RK, Chinmoyee D. A new flavonol glycoside from the flowers of Moringa pterygosperma. J Appl Chem 2012;3:2278-5736.

32. Bouaziz A, Khennouf S, Zarga M, Abdalla S, Baghiani A, Charef N. Phytochemical analysis, hypotensive effect and antioxidant properties of Myrtus communis L. Growing in Algeria. Asian Pac J Trop Biomed 2015;5:19-28.

33. Arya R, Babu V, Ilyas M, Nasim KT. Myricetin 3'-rhamnoside-3galactoside from Buchanania lanzan (Anacardiaceae). Phytochemistry 1992;31:2569-70.

34. Ansari AQ, Ahmed SA, Waheed MA, Juned S. Extraction and determination of antioxidant activity of Withania somnifera Dunal. Eur J Exp Bio 2013;3:502-7

35. Barbosa W, Peres A, Gallori S, Vincieri F. Determination of myricetin derivatives in Chrysobalanus icaco L. (Chrysobalanaceae). Braz J Pharm 2006;16:333-7.

36. Hayder N, Bouhlel I, Skandrani I, Kadri M, Steiman R, Guiraud P, et al. In vitro antioxidant and antigenotoxic potentials of myricetion-3-orhamnoside from Myrtus communis: Modulation of expression of genes involved in cell defence system using c DNA microarray. J Toxicol 2008;22:567-81.

37. Djeradi D, Rahmouni A, Cheriti A. Antioxidant activity of flavonoids: A QSAR modeling using Fukui indices descriptors. J Mol Model 2014;20:2476-83. 